\title{
KESIAPAN MAHASISWA CALON GURU MENGIKUTI PEMBELAJARAN FISIKA SECARA DARING SAAT PANDEMI COVID-19
}

\section{READINESS OF PROSPECTIVE TEACHERS FOLLOWING ONLINE PHYSICS LEARNING DURING COVID-19 PANDEMIC}

\author{
Rita Fitriani ${ }^{1}$ \\ Universitas Maritim \\ Raja Ali Haji, \\ Indonesia $^{1}$ \\ Email: \\ ritaf34@umrah.ac.id
}

IJI Publication

p-ISSN: 2774-1907

e-ISSN: 2774-1915

Vol. 1, No. 2, pp. $90-96$

Maret 2021

Unit Publikasi Ilmiah
Intelektual Madani
Indonesia

Penyebaran Covid-19 terjadi sangat cepat di Indonesia. Oleh karena itu, pemerintah, melalui Menteri Pendidikan dan Kebudayaan mengeluarkan Surat Edaran Nomor 36962/MPK.A/HK/2020 tertanggal 17 Maret 2020. Surat tersebut berisi tentang kebijakan pembelajaran secara daring dan kebijakan baru terkait Bekerja dari Rumah (BDR) dalam rangka peningkatan kewaspadaan pencegahan penyebaran Covid19. Selanjutnya Direktur Jenderal Pendidikan Tinggi menindaklanjuti surat edaran tersebut dan menerbitkan Surat Edaran Nomor
262/E.E2/KM/2020 tanggal 23 Maret 2020 tentang Pembelajaran selama Masa Darurat Pandemi Covid-19. Perguruan tinggi dihimbau untuk menyelenggarakan aktivitas bekerja dari rumah (work from home-WfH) dan mahasiswa untuk belajar dari rumah (study from home-SfH). Adapun tujuan kebijakan tersebut yaitu untuk mendukung dan membantu pemerintah dalam menahan laju pertumbuhan wabah Covid-19.

Pandemi Covid-19 mengakibatkan sistem pendidikan harus beradaptasi dengan kondisi pandemi tersebut. Sistem pendidikan harus berpindah dari pembelajaran tatap 
muka menjadi pembelajaran dalam jaringan (daring). Pembelajaran daring dapat menjangkau kelompok target yang luas, sehingga pembelajaran dapat dilaksanakan dimana saja secara gratis maupun berbayar (Bilfaqih dan Qomarudin, 2015). Melalui jaringan, pembelajaran dapat dilaksanakan secara masif dengan jumlah mahasiswa yang tidak terbatas. Selain itu, pembelajaran daring dapat diikuti oleh mahasiswa tanpa dibatasi lokasi geografis dan kehadiran di kampus, selama akses jaringan tersedia.

Tujuan pembelajaran daring yaitu memberikan layanan pembelajaran yang berkualitas secara daring yang bersifat masif dan terbuka untuk menjangkau audiens atau mahasiswa yang lebih banyak dan lebih luas. Selanjutnya jika dilihat dari segi manfaat pembelajaran daring dapat: 1) meningkatkan mutu pendidikan dan pelatihan dengan memanfaatkan multimedia secara efektif dalam pembelajaran, 2) meningkatkan keterjangkauan pendidikan dan pelatihan yang bermutu melalui penyelenggaraan pembelajaran dalam jaringan, 3) menekan biaya penyelenggaraan pendidikan dan pelatihan yang bermutu melalui pemanfaatan sumber daya bersama.

Pembelajaran daring memiliki beberapa kelebihan yaitu bisa menghasilkan metode pembelajaran yang lebih bervariatif dengan adanya umpan balik, menggabungkan kegiatan belajar terbimbing dengan belajar mandiri, personalisasi pembelajaran berdasarkan kebutuhan peserta didik yang menggunakan simulasi dan permainan (Ghirardini, 2011).

Keberhasilan pembelajaran daring yang dilaksanakan salah satunya bergantung kepada bagaimana proses pembelajaran tersebut dialami oleh mahasiswa. Slameto (2013) mengungkapkan bahwa salah satu faktor psikologi yang berpengaruh bagi tujuan pendidikan dalam pembelajaran yang dilaksanakan adalah faktor kesiapan. Kesiapan adalah keseluruhan kondisi seseorang yang membuatnya siap untuk memberi respon/jawaban di dalam cara tertentu terhadap suatu situasi (Slameto, 2013).

Mahasiswa yang baru pertama kali mengikuti pembelajaran daring akan dihadapkan dengan kondisi dan tantangan baru, yang mana tentu akan sedikit berbeda dibandingkan dengan pembelajaran yang biasa diikuti yakni pembelajaran secara tatap muka di kelas. Kondisi pembelajaran daring ini bisa saja melemahkan konsep diri mahasiswa. Selain itu pembelajaran daring juga bisa mengurangi atau menurunkan tingkat percaya diri mahasiswa untuk mendapatkan suatu target dan keberhasilan dalam belajar. Sehingga faktor kesiapan perlu diperhatikan dengan baik dalam pembelajaran. Dengan mahasiswa memiliki kesiapan belajar maka hasil belajarnya juga akan lebih baik.

Peneliti terdahulu yakni Setiaji dan Dinata (2020) telah menganalisis kesiapan mahasiswa jurusan pendidikan fisika UNY menggunakan e-learning dalam situasi pandemik Covid-19. Setiaji dan Dinata mengemukakan bahwa mahasiswa jurusan pendidikan fisika UNY termasuk dalam kategori siap. Hal ini diperoleh dari indikator yang dianalisis yaitu keterampilan menggunakan smartphone, komputer atau laptop, pemahaman terhadap e-learning, kesiapan menerima materi pembelajaran, dan sikap positif mahasiswa terhadap teknologi komputer dan internet.

Hasil penelitian yang dilakukan oleh Sriwarthini, Syazali, dan Sutisna (2020) menunjukkan bahwa sebagian besar mahasiswa PGSD semester 1 telah siap melaksanakan pembelajaran secara daring dimasa pandemi Covid-19 ini, ditinjau dari kesiapan sarana dan prasarana yang dimiliki, kesiapan dari segi kemampuan penggunaan media/platform pembelajaran daring, dan kesiapan dalam menghadapi kendala yang 
akan muncul pada saat pembelajaran daring dilaksanakan.

Hadiningrum (2018) juga telah melakukan penelitian mengenai kesiapan belajar. Dihasilkan bahwa kesiapan belajar mahasiswa dalam mengikuti perkuliahan Pragmatik terkait bagaimana kondisi awal mahasiswa dalam mengikuti pembelajaran dan melakukan aktivitas pembelajaran. Jika kesiapan diri mahasiswa dalam mengikuti pembelajaran baik maka mahasiswa dapat mengikuti pembelajaran dengan baik.

Oleh karena itu, tujuan dilaksanakannya penelitian ini yaitu untuk mendapatkan informasi kesiapan mahasiswa calon guru mengikuti pembelajaran fisika secara daring saat pandemi Covid-19. Kesiapan mahasiswa ditinjau dari kesiapan lokasi pembelajaran daring, motivasi, sumber belajar, infrastruktur, literasi teknologi, kualitas interaksi akademik secara online, manfaat, faktor pendukung pembelajaran daring.

\section{METODE}

Metode penelitian ini adalah deskriptif kualitatif. Menurut Nurdin dan Hartati (2019), penelitian kualitatif adalah suatu penelitian yang bersumber dari data, memanfaatkan teori yang ada sebagai bahan penjelas dan berakhir dengan sebuah teori.

Responden penelitian ini adalah 20 mahasiswa program studi Pendidikan Kimia yang sedang mengambil mata kuliah Fisika Umum. Data penelitian dikumpulkan melalui penyebaran kuisioner yang berisi 18 butir pertanyaan. Seluruh pertanyaan pada kuisioner terkait dengan kesiapan belajar mahasiswa calon guru dalam mengikuti pembelajaran daring saat pandemi Covid-19 pada mata kuliah Fisika Umum di Prodi Pendidikan Kimia FKIP UMRAH Tanjungpinang.

Kuisioner diakses dan direspon oleh seluruh responden secara online di googleform dengan memastikan bahwa satu mahasiswa hanya dapat mengisi kuisioner 1 kali. Kemudian semua data berupa jawaban mahasiswa tersebut dianalisis dan dijelaskan menggunakan kalimat-kalimat berstruktur dan bermakna.

\section{HASIL DAN DISKUSI}

Hasil penelitian yang telah dilaksanakan disajikan pada tabel berikut.

Tabel 1

Hasil Penelitian yang Diperoleh dari Pengisian Kuisioner oleh Responden

\begin{tabular}{|c|c|c|}
\hline No & Pertanyaan & $\%$ \\
\hline \multicolumn{3}{|c|}{ Lokasi Pembelajaran Daring } \\
\hline \multirow[t]{9}{*}{1.} & \multicolumn{2}{|l|}{$\begin{array}{l}\text { Ananda berada di Kabupaten/Kota } \\
\text { mana saat pembelajaran daring? }\end{array}$} \\
\hline & Kota Tanjungpinang & 40 \\
\hline & Kota Batam & 15 \\
\hline & Kabupaten Bintan & 10 \\
\hline & Kabupaten Karimun & 10 \\
\hline & Kabupaten Natuna & 5 \\
\hline & Kabupaten Kepulauan Anambas & 5 \\
\hline & Kabupaten Lingga & 5 \\
\hline & $\begin{array}{l}\text { Kabupaten/Kota di luar Provinsi } \\
\text { Kepulauan Riau }\end{array}$ & 10 \\
\hline \multicolumn{3}{|c|}{ Motivasi Pembelajaran Daring } \\
\hline \multirow[t]{3}{*}{1.} & \multicolumn{2}{|l|}{$\begin{array}{l}\text { Apakah Ananda menyambut dengan } \\
\text { senang hati pembelajaran daring? }\end{array}$} \\
\hline & $\mathrm{Ya}$ & 75 \\
\hline & Tidak & 25 \\
\hline \multirow[t]{3}{*}{2.} & \multicolumn{2}{|l|}{$\begin{array}{l}\text { Apakah Ananda menetapkan target } \\
\text { pencapaian nilai pada mata kuliah yang } \\
\text { diambil? }\end{array}$} \\
\hline & $\mathrm{Ya}$ & 100 \\
\hline & Tidak & 0 \\
\hline \multicolumn{3}{|c|}{ Persepsi Kesiapan Sumber Belajar } \\
\hline \multirow[t]{3}{*}{1.} & \multicolumn{2}{|l|}{$\begin{array}{l}\text { Apakah Ananda telah mempersiapkan } \\
\text { bahan bacaan atau sumber belajar } \\
\text { sesuai dengan mata kuliah yang } \\
\text { diambil? }\end{array}$} \\
\hline & $\mathrm{Ya}$ & 55 \\
\hline & Tidak & 45 \\
\hline \multicolumn{3}{|c|}{ Persepsi Kesiapan Infrastruktur } \\
\hline \multirow[t]{3}{*}{1.} & \multicolumn{2}{|l|}{$\begin{array}{l}\text { Apakah Ananda memiliki komputer } \\
\text { atau laptop untuk pembelajaran daring? }\end{array}$} \\
\hline & $\mathrm{Ya}$ & 75 \\
\hline & Tidak & 25 \\
\hline \multirow[t]{3}{*}{2.} & \multicolumn{2}{|l|}{$\begin{array}{l}\text { Apakah Ananda memiliki HP android } \\
\text { untuk pembelajaran daring? }\end{array}$} \\
\hline & $\mathrm{Ya}$ & 100 \\
\hline & Tidak & 0 \\
\hline \multirow[t]{3}{*}{3.} & \multicolumn{2}{|l|}{$\begin{array}{l}\text { Apakah Ananda berada di tempat yang } \\
\text { memiliki akses internet memadai untuk } \\
\text { pembelajaran daring? }\end{array}$} \\
\hline & $\mathrm{Ya}$ & 80 \\
\hline & Tidak & 20 \\
\hline 4. & \multicolumn{2}{|l|}{$\begin{array}{l}\text { Apakah Ananda akan selalu memiliki } \\
\text { kuota internet yang memadai untuk }\end{array}$} \\
\hline
\end{tabular}




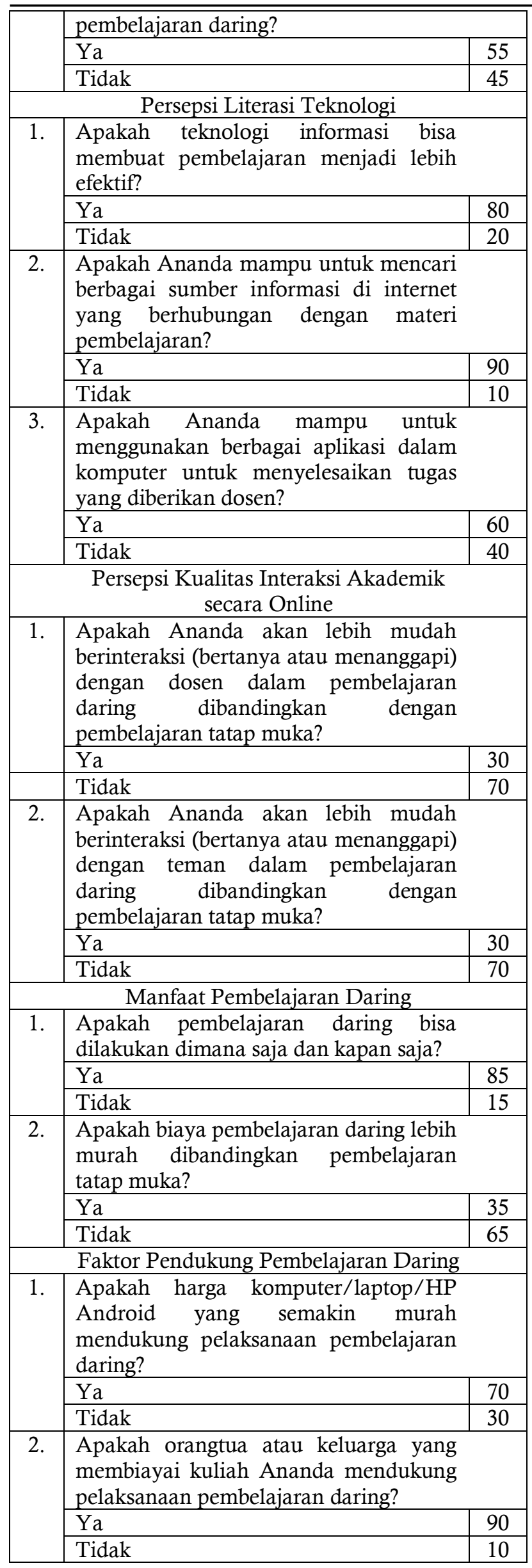

\section{Lokasi Pembelajaran Daring}

Lokasi mahasiswa saat pembelajaran daring terbanyak berada di Kota Tanjungpinang. Kota Tanjungpinang merupakan ibukota Provinsi Kepulauan Riau dimana lokasi kampus UMRAH berada. Di Tanjungpinang sendiri memiliki akses internet yang baik sehingga memungkinkan untuk melaksanakan pembelajaran daring dengan baik.

\section{Motivasi Pembelajaran Daring}

Sebagian besar mahasiswa menyambut dengan senang hati pembelajaran daring yang akan dilaksanakan. Pada pembelajaran daring yang akan dilaksanakan tersebut keseluruhan mahasiswa menetapkan target pencapaian nilai pada mata kuliah yang diambil. Sesuai dengan defenisi motivasi belajar menurut Sardiman (2014) yaitu keseluruhan daya penggerak di dalam diri peserta didik yang menimbulkan kegiatan belajar, yang menjamin kelangsungan dari kegiatan belajar dan memberikan arah pada kegiatan belajar, sehingga tujuan yang dikehendaki oleh subjek belajar itu dapat tercapai. Dimana indikator motivasi adalah adanya dorongan dan kebutuhan dalam belajar, hasrat dan keinginan berhasil, serta adanya harapan dan cita-cita di masa depan (Uno, 2013).

\section{Persepsi Kesiapan Sumber Belajar}

Mahasiswa yang telah mempersiapkan bahan bacaan atau sumber belajar sesuai dengan mata kuliah yang diambil sedikit lebih banyak dibandingkan dengan mahasiswa yang tidak mempersiapkan bahan bacaan atau sumber belajar. Menurut Majid (2013) sumber belajar merupakan berbagai bentuk informasi yang disajikan dalam bentuk media dan dapat digunakan oleh peserta didik sebagai alat bantu belajar untuk melakukan proses perubahan tingkah laku. Bentuk yang bisa digunakan yakni berupa hasil cetak, video, software ataupun berbagai format kombinasi lainnya. Selanjutnya sumber 
belajar menurut Sanjaya (2010) adalah segala sesuatu yang berupa sekumpulan bahan dan dapat dimanfaatkan dalam kepentingan proses pembelajaran untuk memperoleh informasi dan pengalaman, sehingga dapat mempermudah aktivitas belajar. Sumber belajar menurut Sanjaya dapat berasal dari lingkungan sekitar tempat tinggal peserta didik atau bisa juga berasal dari sesuatu yang sengaja dibuat. Sumber belajar yang berasal dari lingkungan contohnya laut, pantai, gunung, dan sebagainya. Sedangkan sumber belajar yang sengaja dibuat contohnya buku, modul, handout, video tutorial, dan sebagainya. Berdasarkan berbagai definisi yang telah dikemukakan sebelumnya, dapat disimpulkan bahwa sumber belajar adalah segala sesuatu baik berupa data, orang, dan wujud tertentu yang dapat digunakan oleh mahasiswa sebagai peserta didik untuk memasilitasinya dalam belajar, baik secara terpisah maupun digabungkan guna memudahkan mahasiswa mencapai tujuan pembelajaran dan meningkatkan kinerjanya dalam mengikuti pembelajaran. Sumber belajar contohnya laut, pantai, gunung, buku, modul, handout, video tutorial, dan sebagainya, dimana pemanfaatannya dapat dirancang secara khusus atau dimanfaatkan dari segala sesuatu yang sudah tersedia. Sumber belajar tentunya dapat digunakan pada pembelajaran non-formal, informal, maupun formal, baik pembelajaran tatap muka maupun pembelajaran daring.

\section{Persepsi Kesiapan Infrastruktur}

Pada saat sekarang ini kepemilikan HP android sudah sangat menjamur di tengahtengah masyarakat, baik tua maupun muda. Sedangkan untuk kepemilikan komputer atau laptop untuk mengikuti pembelajaran daring hanya $75 \%$ mahasiswa saja yang memilikinya. Berdasarkan data diketahui bahwa seluruh mahasiswa memiliki HP android untuk mengikuti pembelajaran daring. Akan tetapi tidak seluruhnya berada di daerah yang memiliki akses internet memadai untuk pembelajaran daring. Selain itu hampir 50\% mahasiswa berpikir tidak akan selalu memiliki kuota internet yang memadai untuk pembelajaran daring.

\section{Persepsi Literasi Teknologi}

Mayoritas mahasiswa mampu untuk mencari berbagai sumber informasi di internet yang berhubungan dengan materi pembelajaran Mayoritas mahasiswa juga mampu menggunakan berbagai aplikasi dalam komputer untuk menyelesaikan tugas yang diberikan dosen. Selain itu mayoritas mahasiswa juga berpendapat bahwa teknologi informasi bisa membuat pembelajaran menjadi lebih efektif. Sebagaimana diketahui bahwa penggunaan teknologi dalam pembelajaran akan menjadikan pembelajaran tersebut efektif dan efisien. Hal ini karena teknologi dapat memudahkan dosen untuk menyampaikan informasi dan materi pembelajaran. Selain itu teknologi juga dapat meningkatkan pemahaman mahasiswa, penyajian informasi lebih menarik, serta memudahkan untuk mendapatkan informasi. Sesuai dengan struktur tuntutan era 4.0 oleh Aon dalam Astini (2019) adalah: (1) literasi dasar; (2) literasi digital; (3) literasi teknologi; dan (4) literasi manusia; (5) literasi budayaekonomi-sosial; (6) karir \& kecakapan hidup; (7) kepemimpinan dan tanggung jawab. Dosen dituntut memfasilitasi, melatih, dan mengembangkan kemampuan struktur tuntutan era 4.0 tersebut bagi mahasiswa pada proses pembelajaran yang dilakukannya.

\section{Persepsi Kualitas Interaksi Akademik Secara Online}

Hanya beberapa mahasiswa yang berpendapat akan lebih mudah berinteraksi seperti bertanya atau menanggapi dengan dosen ataupun dengan teman dalam pembelajaran daring dibandingkan dengan pembelajaran tatap muka. Hal ini dapat 
dipahami karena sebagian besar mahasiswa berasal dari sekolah-sekolah yang tersebar di Provinsi Kepulauan Riau dan sekitarnya. Sekolah-sekolah yang tersebar di Provinsi Kepulauan Riau dan sekitarnya pada umumnya menerapkan pembelajaran tatap muka di kelas yang mana dalam keseharian belajar terjadi interaksi langsung antara guru dan peserta didik.

\section{Manfaat Pembelajaran Daring}

Sebagian besar mahasiswa berpendapat bahwa pembelajaran daring bisa dilakukan dimana saja dan kapan saja. Pembelajaran daring disini memenuhi asas fleksibilitas baik tempat dan juga waktu. Dosen bisa memberikan perkuliahan atau menyelenggarakan pembelajaran secara daring dimana saja dan kapan saja, tidak berbatas oleh waktu dan ruang. Di sisi lain mahasiswa bisa menerima transfer ilmu pengetahuan dari dosen atau mahasiswa lainnya. Pada pembelajaran daring ini interaksi akademik antara dosen dan mahasiswa tidak terbatas, yang artinya bisa dilaksanakan pembelajaran daring tersebut selama 24 jam penuh. Hal ini memungkinkan terjadinya peningkatan kualitas belajar mahasiswa. Dosen bisa mengupload bahan belajar atau sumber belajar dalam berbagai format file pada saat pembelajaran daring. Selain itu, dosen juga bisa melihat postingan mahasiswa dan memberikan umpan balik serta melakukan penilaian terhadap tugas yang dikumpulkan oleh mahasiswa. Saat ini kecanggihan teknologi memberikan kemudahan pada dunia pendidikan untuk melaksanakan pembelajaran, khususnya pada saat pandemi Covid-19. Namun, pembelajaran daring membutuhkan biaya yang tidak lebih murah apabila dibandingkan dengan pembelajaran tatap muka. $\mathrm{Hal}$ ini disebabkan karena kelengkapan alat teknologi informasi, seperti smartphone, laptop, dan sebagainya yang harus selalu terisi dengan internet terkoneksi. jaringan

tentunya menguras biaya yang tidak sedikit.

\section{Faktor Pendukung Pembelajaran Daring}

Pembelajaran daring membutuhkan dukungan dari berbagai faktor agar pembelajaran menjadi efektif dan efisien. Berdasarkan hasil kuisioner sebagian besar mahasiswa berpendapat bahwa harga komputer/laptop/HP Android yang semakin murah mendukung pelaksanaan pembelajaran daring. Selain itu sebagian besar mahasiswa juga mendapat dukungan dari orangtua atau keluarga yang membiayai kuliah dalam pelaksanaan pembelajaran daring.

\section{KESIMPULAN}

Kesiapan mahasiswa untuk mengikuti pembelajaran sangat diperlukan dalam rangka menciptakan pembelajaran efektif dan efisien. Pada mata kuliah Fisika Umum yang diikuti oleh mahasiswa calon guru dari prodi Pendidikan Kimia, kesiapan belajar mahasiswa yang diteliti meliputi persiapan lokasi pembelajaran daring, motivasi pembelajaran daring, persepsi kesiapan sumber belajar, persepsi kesiapan infrastruktur, persepsi literasi teknologi, persepsi kualitas interaksi akademik secara online, manfaat pembelajaran daring, dan faktor pendukung pembelajaran daring. Berdasarkan hasil penelitian yang telah dilakukan, dapat disimpulkan bahwa sebagian besar mahasiswa calon guru dari prodi Pendidikan Kimia sudah mempersiapkan diri dengan baik untuk mengikuti pembelajaran fisika secara daring saat pandemi Covid-19.

\section{REFERENSI}

Astini, N. K. S. (2019). Pentingnya Literasi Teknologi Informasi dan Komunikasi Bagi Guru Sekolah Dasar untuk Menyiapkan Generasi Milenial, Tantangan dan Peluang 
Dunia Pendidikan di Era 4.0. Prosiding, 113-120.

Bilfaqih, Y., \& Qomarudin, M. N. (2015). Esensi Pengembangan Pembelajaran Daring. Yogyakarta: E Publish.

Darojat, O. Susilo, A. \& Suhardi, D. A. (2019). Survei Kesiapan dan Kepuasan Mahasiswa Terhadap Layanan Proses Pembelajaran dalam Jaringan Universitas Terbuka Saat Pandemic Covid 19. Jurnal Pendidikan Terbuka Dan Jarak Jauh, 20(2), 114-130.

Faslah, R., \& Santoso, H. B. (2017). Analisis Kesiapan Implementasi E-Learning Progresif Aktual Menggunakan E-Learning Readiness Model. POSITIF:Jurnal Sistem

Dan Teknologi Informasi, 3(2), 113.

Ghirardini, B. (2011). E-learning Methodologies. Germany: Federal Ministry of Food, Agriculture and Consumer Protection.

Hadiningrum, I. (2018). Analisis Kesiapan Belajar Mahasiswa Dalam Mengikuti Mata Kuliah Pragmatics. Pengembangan Sumber Daya Perdesaan dan Kearifan Lokal Berkelanjutan, Prosiding, 222-229.

Kumalasari, D \& Akmal, S. Z., (2020). Resiliensi Akademik dan Kepuasan Belajar Daring di Masa Pandemi Covid-19: Peran Mediasi Kesiapan Belajar Daring. Jurnal Psikologi Indonesia. 9(2), 353-368.

Majid, A. (2013). Strategi Pembelajaran. Bandung: Remaja Rosdakarya.

Nichols, M., \& McLachlan, C. (2006). ELearning and Early Childhood Teacher Education: What Does the Future Hold? . He Kupu (The Word), 1(1),17-28.

Priyono, P. K., Rusyani, Y, \& Hartono, B. (2020). Kesiapan Mahasiswa Pada Pembelajaran Dalam Jaringan (Daring) Saat Pandemi Covid-19 di Stikes Duta Gama Klaten.

Redaputri, A. P., Prastyo, Y.D., \& Barusman, M. Y. (2021). Analisis Kepuasan Mahasiswa dalam Pelaksanaan Pembelajaran Online di Era Pandemi Covid19. Lectura: Jurnal Pendidikan,12(1).
Sanjaya, W. (2010). Strategi Pembelajaran Berorientasi Standar Proses Pendidikan. Jakarta: Kencana Prenada.

Sardiman. (2014). Interaksi dan Motivasi Belajar Mengajar. Jakarta: Rajawali Pers.

Setiaji, B \& Dinata, C. A. P. (2020). Analisis Kesiapan Mahasiswa Jurusan Pendidikan Fisika Menggunakan E-Learning dalam Situasi Pandemi Covid-19. Jurnal Inovasi Pendidikan IPA, 6 (1), 59-70.

Slameto, (2013). Belajar dan Faktor-faktor yang Mempengaruhinya. Jakarta: PT. Rineka Cipta.

Sriwarthini, N. L.P. N., Syazali, M., \& Sutisna, D. (2020). Kesiapan Mahasiswa Menghadapi Pembelajaran Daring di Masa Pandemi Covid 19. RESIPROKAL, 2(2), 184-191.

Uno, B. H. (2013). Teori Motivasi dan Pengukurannya: Analisis di Bidang Pendidikan. Jakarta: Bumi Aksara.

Waryanto, N. H., \& Insani, N. (2013). Tingkat Kesiapan (Readiness) Implementasi Elearning Di Sekolah Menengah Atas Kota Yogyakarta. Jurnal Pendidikan Matematika dan Sains, 1(2), 117-124. 